\title{
Potential Protective Role of Sitagliptin (Januvia) Against Acetaminophen-Induced Hepatotoxicity in Adult Albino Rats
}

\author{
Mohamed F. Khodeary ${ }^{1 *}$, Sherifa Abdel El Salam Morsy ${ }^{2}$
}

\begin{tabular}{|c|c|}
\hline & ICT \\
\hline $\begin{array}{l}\text { KEYWORDS } \\
\text { Sitagliptin, } \\
\text { Acetaminophen, } \\
\text { Hepatoprotective, } \\
\text { Enzymatic and Oxidative } \\
\text { stress biomarkers. }\end{array}$ & $\begin{array}{l}\text { Acetaminophen (APAP) is a commonly used analgesic-antipyretic drug. } \\
\text { Overdose of APAP is significant global clinical problem in humans. Sitagliptin (Sitg) } \\
\text { an anti-diabetic drug, has shown protective effects against organs toxicities. This } \\
\text { work aimed to evaluate the protective effect of Sitg against APAP-induced } \\
\text { hepatotoxicity. Forty male rats were divided into four equal groups. Group-I } \\
\text { (control; C-GP; distilled water), Group-II (Sitg-GP; 20-mg/kg), Group-III (APAP- } \\
\text { GP; 500-mg/kg), and Group-IV (Sitg+APAP-GP; 20-mg/kg+500-mg/kg) pretreated } \\
\text { with Sitg followed 2-hour later by APAP. The dosages were given once daily by } \\
\text { gavage for 15 days and then blood and liver specimens were collected. Liver } \\
\text { biomarkers were assayed in sera and included enzym (aspartate } \\
\text { transaminase=AST; alanine transaminase=ALT; alkaline phosphatase=ALP; } \\
\text { gamma-glutamyltransferase=GGT; lactate dehydrogenase=LDH), bilirubin (total } \\
\text { bilirubin=TB; direct bilirubin=DB; indirect bilirubin=IB), and proteins (total } \\
\text { protein=TP; albumin=ALB; globulin=GLB). Oxidative stress biomarkers were } \\
\text { estimated in homogenates and included antioxidants (superoxide dismutase=SOD; } \\
\text { catalase=CAT; glutathione peroxidase=GPx; glutathione-S-transferase=GST; } \\
\text { glutathione=GSH) and oxidative malondialdehyde (MDA) besides tissue total redox } \\
\text { status (total oxidative status=TOS; total antioxidant capacity=TAC; oxidative stress } \\
\text { index=OSI; OSI=TOS/TAC). The hepatic lesions were semi-quantitatively scored. In } \\
\text { APAP-GP, concentrations of all enzymes and bilirubin, MDA, TOS, and OSI were } \\
\text { significantly increased, while levels of all proteins, antioxidants, and TAC were } \\
\text { significantly decreased. Histopathological changes showed distorted architecture, } \\
\text { increased fibrous deposition, and reduced glycogen contents. Pretreatment with Sitg } \\
\text { markedly prevented APAP-induced biochemical and histopathological } \\
\text { abnormalities. Sitg possess remarkable hepatoprotective effects against APAP- } \\
\text { induced hepatotoxicity and may be useful in treatment of APAP-poisoned patients } \\
\text { with diabetes mellitus. }\end{array}$ \\
\hline
\end{tabular}

\section{Introduction}

Drug-induced hepatotoxicity is an urgent clinical problematic phenomenon worldwide. One of these compounds is the most commonly utilized over-the-counter analgesicsantipyretics medication acetaminophen (paracetamol; $\quad$ N-acetyl-p-aminophenol;

\footnotetext{
${ }^{(1)}$ Departments of Forensic Medicine and Clinical Toxicology, Faculty of Medicine, Benha University

${ }^{(2)}$ Histology and Cell Biology, Faculty of Medicine, Benha University

*Corresponding author: Tel: 01280191596; E-mail: smfarid_2013@yahoo.com
}

APAP). APAP is well tolerated and has a low toxicity in regard to aspirin. In the United States, it has been estimated that about 10 to 20 thousand tons of APAP are consumed each year as a therapeutic agent. The easy accessibility and low price can mask the potential danger of APAP misuse during intentional or unintentional ingestion with subsequent occurrence of hepatocellular damage in both humans and experimental animals (Yano and Dolder, 2002; Jaeschke et al., 2010).

Single APAP overdose is a leading cause of more than 100,000 calls to Poison Control 
Centers per year and accounts for more than 56,000 emergency visits, 2,600 hospital admissions, and an estimated 458 deaths from acute liver cell failure each year in the USA (Lee, 2004).

The toxicity of APAP is associated with formation of reactive metabolite derived from hepatic cytochrome P-450 metabolism. At therapeutic doses, APAP is mainly metabolized by glucuronidation and sulfation into inactive metabolites, while small part undergoes metabolism by the cytochrome p450 system into the reactive toxic metabolite $\mathrm{N}$-acetyl-pbenzoquinone imine (NAPQI). Under normal conditions, NAPQI is rapidly converted to nontoxic metabolite by conjugation with glutathione $(\mathrm{GSH})$ and eliminated via the kidney. However, at APAP overdoses, the essential routes become saturated and NAPQI production greatly exceeds the organ capacity of its detoxification by GSH. Then, NAPQI reacts with various hepatocellular proteins and causes liver injury associated with oxidative stress (Lancaster et al., 2014; Kane et al., 2016).

Increment of liver enzymes levels can be detected after 12-36 hours of the drug overdose (Dart et al., 2006). Following the changes in cellular pattern and biochemical indices, clinical manifestations such as jaundice, encephalopathy, cerebral edema, coagulopathy, and hepatic failure are developed (Fontana, 2008).

Sitagliptin (Sitg), an oral antihyperglycemic or anti-diabetic drug of the dipeptidyl peptidase-4 (DPP-4) inhibitor class, is currently used for the management of type II diabetes mellitus through the inhibition of DPP-4 enzyme activities, leading to prevention of the breakdown of endogenous incretin hormones, glucagon-like peptide-1 and glucose-dependent insulinotropic peptide, and consequently increases the function and bioavailability of these hormones (Itou et al., 2013).
The DPP-4 inhibitor (Sitg) has depicted protective effects against different types of cardiovascular and renal injuries (Alam et al., 2015; Nuransoy et al., 2015). Also, Sitg has shown a hepatoprotective action against experimentally-induced liver injury. Its protective actions are possibly mediated via modulations of different signaling pathways involved in hepatocellular damage with subsequent amelioration of inflammatory processes, lipid metabolism, and oxidative stress damage (Onoyama et al., 2015; AboHaded et al., 2017).

Several studies have spectacled that antioxidants agents may effectively protect the liver against APAP-induced injury (Sayed and El-Kordy, 2014; Verma et al., 2016; Elbe et al., 2018).To the best of our knowledge, the effect of sitagliptin on APAP-induced hepatotoxicity has not been studied.

The aim of this experimental study was to investigate the possible protective effect of pretreatment with Sitg against APAP-induced hepatotoxicity in rats by assessment of its impact on liver enzymes, oxidant/antioxidant defense system, total redox status, and histological structure.

\section{Material and Methods}

\section{Chemicals}

Januvia tablets (highly water soluble sitagliptin phosphate monohydrate, Sitg) were purchased from Merck and Co., Inc. "MSD" (Whitehouse Station, New Jersey, USA, each film-coated tablet contains 100-mg Sitg). Paracetamol (APAP) tablets were obtained from El-Nasr Pharmaceutical Chemicals Co. "ADWIC" (Cairo, Egypt, each tablet contains 500-mg APAP). Both drugs were given orally through a gastric tube at doses of $20 \mathrm{mg} / \mathrm{kg} / \mathrm{day}$ for Sitg (Abo-Haded et al., 2017) and 500 
$\mathrm{mg} / \mathrm{kg} /$ day for APAP (Sayed and El-Kordy, 2014).The assay kits used for biochemical measurements of liver function and oxidative stress biomarkers were purchased from Biodiagnostic Company (Dokki, Giza, Egypt). The other used chemicals were of highest grade commercially available.

\section{Animals:}

Forty male adult albino rats, weighing 180-200-gram at the start of the experiment, were used in this study. They were obtained from Helwan Farm (Holding Company for Biological Products and Vaccines, VACSERA, Egypt). The animals were housed in individual properly ventilated cages (ten rats per cage), in the animal facility for 1 week before the start of the experiment for acclimatization. They were housed in standard conditions of temperature $\left(25 \pm 2^{\circ} \mathrm{C}\right)$, humidity $(50 \pm 5 \%)$ and 12 -hour dark/light cycles and given standard laboratory animal diet with tap water ad libitum. All experimental procedures adhered strictly to institutional and international ethical guidelines of the care and use of laboratory animals and have been approved by the ethical committee, Faculty of medicine, Benha University, Egypt.

\section{Experimental design}

Rats were randomly divided into four equal groups (each contained 10 rats) as follows:

Group-I (C-GP): control group that received distilled water only.

Group-II (Sitg-GP): received Sitagliptin (Sitg) at $20 \mathrm{mg} / \mathrm{kg} /$ day.

Group-III (APAP-GP): received acetaminophen (APAP) at $500 \mathrm{mg} / \mathrm{kg} /$ day.

Group-IV (Sitg+APAP-GP): pretreated with Sitg $20 \mathrm{mg} / \mathrm{kg} /$ day followed 2-hour later byAPAP $500 \mathrm{mg} / \mathrm{kg} /$ day.

Before each administration, both drugs were crushed and prepared freshly by dissolving in distilled water to obtain the necessary drug concentration in $1 \mathrm{ml}$ solution. All Animals were fasted for 4 hours, weighed before gavage, and received their corresponding substance dosage once daily for 15 consecutive days. The doses were calculated according to animals' daily weights.

\section{Blood and liver sampling}

One day after the last dose, the animals were fasted, weighed, anesthetized by inhalation of diethyl ether, and then subjected to thoraco-abdominal incision to collect blood and liver samples for biochemical assays of liver enzymes activities and histopathological examination, respectively. Finally, animals were sacrificed by cervical dislocation.

Blood samples were collected from the descending aorta by needle aspiration into clean, dry centrifuge tubes, allowed to clot inside incubator at $37^{\circ} \mathrm{C}$ for 15 minutes, and centrifuged at 3000 revolutions per minute (rpm) for 15 minutes to obtain the sera. The clear non-haemolysed supernatant sera were quickly transferred into Eppendorf tubes and immediately preserved in freezer at $-20^{\circ} \mathrm{C}$ till been assayed for activities of liver marker enzymes.

Each liver was dissected, removed, rinsed with normal physiological saline solution $(0.9 \% \mathrm{NaCl})$ to remove blood and adhering debris, trimmed of all fat, dried on a filter paper, and weighted. Absolute and relative weights of livers were recorded [relative weight $=($ liver weight/body weight $) \times 100)$ ]

Prior to dissection, liver was perfused through the heart or the ascending aorta with $50 \mathrm{mmol} / \mathrm{L}$ sodium phosphate buffer saline (100 mmol/L Na $\left.\mathrm{LPO}_{4} / \mathrm{NaH}_{2} \mathrm{PO}_{4} ; \mathrm{pH} 7.4\right)$ and $0.1 \mathrm{mmol} / \mathrm{L}$ ethylenediaminetetraacetic acid to remove any red blood cells and clots. Then small part from each liver was homogenized 
$(1: 10 \% \mathrm{w} / \mathrm{v} ;$ gram tissue $/ 10 \mathrm{ml}$ buffer solution) in ice-cold phosphate-buffered saline solution (137 mmol/L NaCl, $2.7 \mathrm{mmol} / \mathrm{L} \mathrm{KCl}, 10$ $\mathrm{mmol} / \mathrm{L} \quad \mathrm{Na} 2 \mathrm{HPO} 4,2 \mathrm{mmol} / \mathrm{L} \quad \mathrm{KH}_{2} \mathrm{PO}_{4}, \mathrm{pH}$ 7.4) using teflon homogenizer (Glas-Col, Terre Haute, USA). The tissue homogenates were centrifuged at $10,000 \mathrm{rpm}$ for 20 minutes at $4^{\circ} \mathrm{C}$ and the resultant supernatants were transferred into Eppendorf tubes and kept at $20^{\circ} \mathrm{C}$ in a deep freezer until used for the determination of some oxidative/antioxidant parameters of liver tissue.

Other small pieces from each liver were kept in $10 \%$ neutral formalin solution for histopathological study.

\section{Measurement of liver function biomarkers}

The extracted sera were used for spectrophotometric measurement of aspartate transaminase (AST) and alanine transaminase (ALT) (Reitman and Frankel, 1957), alkaline phosphatase (ALP) (Belfield and Goldberg, 1971), gamma-glutamyltransferase (GGT) (Szasz, 1969), lactate dehydrogenase (LDH) (Buhl and Jackson, 1978), total bilirubin (TB) and direct bilirubin (DB) (Walters and Gerarde, 1970), total protein (TP) (Gornall et al., 1949), and albumin (ALB) (Doumas et al., 1971). Also, the values of indirect bilirubin (IB, calculated by subtracting $\mathrm{DB}$ from $\mathrm{TB}$ ) and globulin (GLB, calculated by subtracting ALB from TP) were calculated. All previously mentioned biomarkers were measured according to the details given in Biodiagnostic kit's instructions (Biodiagnostic Company, Dokki, Giza, Egypt).

Assessment of oxidative stress biomarkers in liver tissue

Aliquots of the supernatants were used for colorimetri cestimation of enzymatic antioxidants such as superoxide dismutase (SOD) (Nishikimi et al., 1972), catalase (CAT)
(Aebi, 1984), glutathione peroxidase (GPx) (Paglia and Valentine, 1967), glutathione-Stransferase (GST) (Habig et al., 1974), nonenzymatic antioxidant like reduced glutathione (GSH) (Beutler et al., 1963), and thiobarbituric acid reactive substances (TBARS) marker for lipid peroxidation (LPO) end product malondialdehyde (MDA)(Satoh, 1978) along with total redox status profiles like total oxidative status (TOS) (Erel, 2005), total antioxidant capacity (TAC) (Erel, 2004), and oxidative stress index (OSI) (an indicator of the degree of oxidative stress).The OSI value for the hepatic samples was calculated as OSI (Arbitrary unit) $=$ TOS (mmol $\mathrm{H}_{2} \mathrm{O}_{2}$ equivalent/g protein)/TAC (mmol Trolox equivalent/g protein). The assayed method for each concerned parameter was performed according to the principals given in the kit's instructions.

\section{Histopathological preparations and analysis}

The liver specimens from all rats of all groups were fixed in $10 \%$ formol saline, subsequently dehydrated in ascending grades of alcohol, cleaned by xylene, and embedded in paraffin wax, then sectioned at $4 \mu \mathrm{m}$ thicknesses by a microtome. The obtained tissue sections were collected on glass slides (two slides per rat with each slide contained two non-serial tissue sections), deparaffinized, and stained with Hematoxylin and Eosin ( $\mathrm{Hx} \&$ $\mathrm{E}$; hepatocytes appeared with blue nuclei and red or pink cytoplasm) (Gamble and Wilson, 2002), Masson's Trichrome (MT; the connective tissue appeared blue) (Jones, 2002), and Periodic Acid-Schiff Reaction (PAS; the muco-polysaccharide material appeared purplemagenta) (Totty, 2002). Mounted slides were examined and photographed using Leica DM500 binocular light microscope with an attached ICC50 HD color digital camera (Leica Microsystems Ltd, Heerbrugg, Switzerlan) at Department of Pathology, Benha Faculty of Medicine. 
A total of 40 field areas per each animal were randomly chosen from Hx\&E, MT, PAS stained sections and examined microscopically for histopathological changes, the extent of fibrosis, and the intensity of glycogen staining, respectively, at $200 \mathrm{x}$ magnification by an expert pathologist in a blind fashion. Among the three stained sections, the type and severity of hepatic lesions were semi-quantitatively scored.

Among the experimental groups, the number and percentage of animals with normal as well as abnormal histopathological findings were recorded. The severity of lesions per each rat was evaluated using a semi-quantitative scale as previously described by Tokyol et al. (2006).

All sections were evaluated for type of hepatic damage such as hepatocyte necrosis, hemorrhage, intracellular vacuolization, vascular congestion, sinusoidal dilatation, and inflammatory infiltration in 10 different fields per each section. The hepatic damage was semi-quantitatively graded as $0=$ absent, $1=$ mild, $2=$ moderate, and $3=$ severe for each criterion with a maximum score of 18 (Batcioglu et al., 2009). Histological grading of hepatic fibrosis was determined using the semiquantitative method mentioned by $\mathrm{He}$ et al. (2004). The intensity grading of PAS stain was determined according to the method of Çeriğ et al. (2016).

\section{Statistical analysis}

The collected data were scored, tabulated, and analyzed using Statistical
Package for the Social Sciences version 16 software (SPSS, Chicago, IL). Quantitative data were expressed as mean and standard error of the mean (mean \pm SEM). Chi-square test $\left(\mathrm{X}^{2}\right)$ and one-way analysis of variance (ANOVA) were used as tests of significance. Significant ANOVA was followed by post-hoc Tukey HSD (Honest Significant Difference) test for multiple comparisons to detect significant pairs and values of $\mathrm{P}<0.05$ were considered statistically significantly different.

\section{Results}

No deaths were recorded among the studied groups after 15 days of post-oral treatment.

Generally, statistically non-significant differences were found between Sitg-GP and C-GP regarding to all examined parameters. Similarly, the present data showed non-significant differences between Sitg + APAP-GP and both Sitg-GP and C-GP concerning to almost all investigated variables. Thus, non-significant results between these groups were excluded to simplify data comparison and interpretation.

Table (1) shows the effects of Sitg pretreatment on APAP-induced changes in body weights and liver weights along with liver/body weight ratio. The mean values of absolute and relative liver weights of APAPGP exhibited significant increases as compared to Sitg-GP and C-GP groups. However, the mean values of both liver weights in Sitg + APAP - GP displayed significant decreases as compared to the APAP-GP values. 
Table (1): One-way analysis of variance (ANOVA) statistical differences among the experimental groups regarding to IBW, FBW, BWG, ALW, and RLW.

\begin{tabular}{|l|c|c|c|c|c|}
\hline \multirow{2}{*}{ Groups } & \multicolumn{5}{c|}{ Parameters } \\
\cline { 2 - 6 } & \multicolumn{3}{|c|}{ Body weight (g) } & \multicolumn{2}{c|}{ Liver weight (g) } \\
\cline { 2 - 6 } & Initial & Final & Gain & Absolute & Relative \\
\hline C-GP & $192.3 \pm 2.10$ & $222.6 \pm 3.12$ & $30.3 \pm 1.05$ & $8.93 \pm 0.09$ & $4.02 \pm 0.04$ \\
\hline Sitg-GP & $188.1 \pm 1.81$ & $216.8 \pm 2.65$ & $28.7 \pm 1.32$ & $8.98 \pm 0.18$ & $4.14 \pm 0.05$ \\
\hline APAP-GP & $187.8 \pm 1.96$ & $215.4 \pm 2.47$ & $27.6 \pm 1.07$ & $11.57 \pm 0.42$ & $5.36 \pm 0.14$ \\
\hline Sitg+APAP-GP & $190.2 \pm 1.74$ & $219.3 \pm 1.78$ & $29.1 \pm 1.14$ & $9.35 \pm 0.15$ & $4.26 \pm 0.04$ \\
\hline Multiple comparisons & 0.415 & 0.387 & 0.759 & 0.999 & 0.692 \\
\hline C versus Sitg & 0.354 & 0.208 & 0.359 & $0.000^{*}$ & $0.000^{*}$ \\
\hline C versus APAP & 0.863 & 0.797 & 0.881 & 0.626 & 0.138 \\
\hline C versus Sitg + APAP & 0.999 & 0.980 & 0.905 & $0.000^{*}$ & $0.000^{*}$ \\
\hline Sitg versus APAP & 0.863 & 0.899 & 0.995 & 0.704 & 0.681 \\
\hline Sitg versus Sitg + APAP & 0.81 & 0.703 & 0.793 & $0.000^{*}$ & $0.000^{*}$ \\
\hline APAP versus Sitg + APAP &
\end{tabular}

$\mathrm{C}=$ Control; Sitg=Sitagliptin; APAP=Acetaminophen; $\mathrm{g}=\mathrm{Gram}$; IBW=Initial body weight; FBW=Final body weight; $\mathrm{BWG}=$ Body weight gain; $\mathrm{ALW}=\mathrm{Absolute}$ liver weight; $\mathrm{RLW}=$ Relative liver weight. Each value represented a mean of 10 -animals \pm SEM (standard error of the mean). $\mathrm{P}=$ Probability; $*=$ Significant difference.

Tables (2-4) represent the effects of Sitg pretreatment on APAP-induced alterations in liver biomarker parameters. As illustrates in Table (2), there were significant increases in all investigated serum liver enzyme biomarkers "AST, ALT, ALP, GGT, and
LDH" of APAP-GPwhen compared with SitgGP and C-GP. However, the mean levels of these enzymatic parameters were found to be significantly lower in Sitg+APAP-GP when compared with their corresponding figures in APAP-GP.

Table (2): One-way analysis of variance (ANOVA) statistical differences among the experimental groups concerning to the serum levels of AST, ALT, ALP, GGT, and LDH.

\begin{tabular}{|l|c|c|c|c|c|}
\hline \multirow{2}{*}{ Groups } & \multicolumn{5}{c|}{ Parameters } \\
\cline { 2 - 6 } & AST (U/L) & ALT (U/L) & ALP (U/L) & GGT (U/L) & LDH (U/L) \\
\hline C-GP & $29.45 \pm 1.51$ & $27.86 \pm 1.42$ & $77.42 \pm 1$ & $25.46 \pm 2.16$ & $162.78 \pm 8.72$ \\
\hline Sitg-GP & $28.67 \pm 1.48$ & $26.72 \pm 0.81$ & $74.47 \pm 1.37$ & $23.66 \pm 1.44$ & $159.58 \pm 7.52$ \\
\hline APAP-GP & $81.52 \pm 5.49$ & $76.92 \pm 3.48$ & $176.66 \pm 1.47$ & $71.84 \pm 3.41$ & $653.19 \pm 39.1$ \\
\hline Sitg +APAP-GP & $32.78 \pm 2.17$ & $29.88 \pm 1.40$ & $79.22 \pm 1.25$ & $30.16 \pm 2.20$ & $211.77 \pm 4.45$ \\
\hline Multiple comparison & 0.998 & 0.979 & 0.126 & 0.952 & 1 \\
\hline C versus Sitg & $0.000^{*}$ & $0.000^{*}$ & $0.000^{*}$ & $0.000^{*}$ & $0.000^{*}$ \\
\hline C versus APAP & 0.876 & 0.897 & 0.673 & 0.52 & 0.343 \\
\hline C versus Sitg+APAP & $0.000^{*}$ & $0.000^{*}$ & $0.000^{*}$ & $0.000^{*}$ & $0.000^{*}$ \\
\hline Sitg versus APAP & 0.791 & 0.697 & 0.06 & 0.242 & 0.289 \\
\hline Sitg versus Sitg+APAP & $0.000^{*}$ & $0.000^{*}$ & $0.000^{*}$ & $0.000^{*}$ & $0.000^{*}$ \\
\hline APAP versus Sitg+APAP &
\end{tabular}

$\mathrm{C}=$ Control; Sitg=Sitagliptin; $\mathrm{APAP}=$ Acetaminophen; AST=Aspartate transaminase; ALT $=$ Alanin transaminase; $\mathrm{ALP}=$ Alkaline phosphatase; GGT= Gamma-glutamyltransferase; $\mathrm{LDH}=$ Lactate dehydrogenase. Each value represented a mean of 10 -animals \pm SEM (standard error of the mean). $P=$ Probability; $*=$ Significant difference. 
As delineates in table (3), the mean levels of serum TB, DB, and calculated IB displayed significant increases in APAP-GP as compared to Sitg-GP and C-GP. On the other hand, the mean levels of these bilirubin parameters were noticed to be significantly lower in Sitg+APAP-GP when compared with their corresponding values in APAP-GP.

Table (3): One-way analysis of variance (ANOVA) statistical differences among the experimental groups concerning to the serum levels of TB, DB, and calculated IB.

\begin{tabular}{|l|c|c|c|}
\hline \multirow{2}{*}{ Groups } & \multicolumn{3}{c|}{ Parameters } \\
\cline { 2 - 4 } & TB (mg/dL) & DB (mg/dL) & IB (mg/dL) \\
\hline C-GP & $0.63 \pm 0.07$ & $0.33 \pm 0.03$ & $0.30 \pm 0.05$ \\
\hline Sitg-GP & $0.60 \pm 0.04$ & $0.31 \pm 0.04$ & $0.28 \pm 0.04$ \\
\hline APAP-GP & $3.77 \pm 0.21$ & $2.15 \pm 0.13$ & $1.62 \pm 0.29$ \\
\hline Sitg+APAP-GP & $0.89 \pm 0.02$ & $0.52 \pm 0.03$ & $0.37 \pm 0.03$ \\
\hline Multiple comparison & 0.998 & 0.999 & 1 \\
\hline C versus Sitg & $0.000^{*}$ & $0.000^{*}$ & $0.000^{*}$ \\
\hline C versus APAP & 0.356 & 0.256 & 0.985 \\
\hline C versus Sitg+APAP & $0.000^{*}$ & $0.000^{*}$ & $0.000^{*}$ \\
\hline Sitg versus APAP & 0.268 & 0.195 & 0.976 \\
\hline Sitg versus Sitg+APAP & $0.000^{*}$ & $0.000^{*}$ & $0.000^{*}$ \\
\hline APAP versus Sitg+APAP &
\end{tabular}

$\mathrm{C}=$ Control; Sitg $=$ Sitagliptin; $\mathrm{APAP}=$ Acetaminophen; $\mathrm{TB}=$ Total bilirubin; $\mathrm{DB}=$ Direct bilirubin; $\mathrm{IB}=$ Indirect bilirubin. Each value represented a mean of 10 -animals \pm SEM (standard error of the mean). $P=$ Probability; ${ }^{*}=$ Significant difference.

As exhibits in table (4), statistical data analyses of the mean serum levels of TP, ALB, and GLB was significantly decreased in APAPGP when compared with those values in SitgGP and C-GP.Otherwise, the mean values of these protein variables were reported to be significantly higher in Sitg+APAP-GP when compared with their corresponding figures in APAP-GP.

Table (4): One-way analysis of variance (ANOVA) statistical differences among the experimental groups according to the serum levels of TP, ALB, and calculated GLB.

\begin{tabular}{|l|c|c|c|}
\hline \multirow{2}{*}{ Groups } & \multicolumn{3}{c|}{ Parameters } \\
\cline { 2 - 4 } & TP $(\mathbf{g} / \mathbf{d L})$ & ALB $\mathbf{( g / d L )}$ & GLB (g/dL) \\
\hline C-GP & $7.48 \pm 0.19$ & $3.85 \pm 0.15$ & $3.63 \pm 0.22$ \\
\hline Sitg-GP & $7.79 \pm 0.29$ & $4.11 \pm 0.1$ & $3.68 \pm 0.28$ \\
\hline APAP-GP & $4.76 \pm 0.28$ & $2.96 \pm 0.16$ & $1.81 \pm 0.32$ \\
\hline Sitg+APAP-GP & $7.11 \pm 0.26$ & $4.1 \pm 0.31$ & $3 \pm 0.21$ \\
\hline Multiple comparison & 0.83 & 0.776 & 0.999 \\
\hline C versus Sitg & $0.000^{*}$ & $0.013^{*}$ & $0.000^{*}$ \\
\hline C versus APAP & 0.752 & 0.818 & 0.375 \\
\hline C versus Sitg+APAP & $0.000^{*}$ & $0.001^{*}$ & $0.000^{*}$ \\
\hline Sitgversus APAP & 0.269 & 0.1 & 0.31 \\
\hline Sitgversus Sitg+APAP & $0.000^{*}$ & $0.001^{*}$ & $0.012^{*}$ \\
\hline APAP versus Sitg+APAP &
\end{tabular}

$\mathrm{C}=$ Control; Sitg=Sitagliptin; $\mathrm{APAP}=\mathrm{Acetaminophen;} \mathrm{TP}=$ Total protein; $\mathrm{ALB}=\mathrm{Albumin} ; \mathrm{GLB}=$ Globulin. Each value represented a mean of 10 -animals \pm SEM (standard error of the mean). $P=$ Probability; $*=$ Significant difference. 
Tables (5 and 6), represent the effects of Sitg pretreatment on APAP-induced tissue oxidative stress with disturbances in oxidantantioxidant and total redox status biomarkers profiles.

As appears in table (5), there were significant decreases in the mean tissue concentrations of all antioxidant variables (SOD, CAT, GPx, GST, and GSH) coupled with significant increases in oxidative MDA levels in APAP-GP when compared with their corresponding values of Sitg-GP and C-GP. On the other side, the mean hepatic levels of all antioxidant parameters were reported to be significantly higher, while MDA values were significantly lower in Sitg+APAP-GP compared to the APAP-GP figures. In contrast, the mean values of all antioxidants and MDA were significantly lower and higher, respectively, in Sitg+APAP-GP compared to the Sitg-GP values.

Table (5): One-way analysis of variance (ANOVA) statistical differences among the experimental groups as regards the levels of SOD, CAT, GSH, GPx, GST, and MDA in hepatic tissue.

\begin{tabular}{|c|c|c|c|c|c|c|}
\hline \multirow[b]{2}{*}{ Groups } & \multicolumn{6}{|c|}{ Parameters } \\
\hline & $\begin{array}{c}\text { SOD } \\
\text { (U/mg } \\
\text { protein) }\end{array}$ & $\begin{array}{c}\text { CAT } \\
\text { (U/mg } \\
\text { protein) }\end{array}$ & $\begin{array}{c}\text { GPx } \\
\text { (U/mg } \\
\text { protein) }\end{array}$ & $\begin{array}{c}\text { GST } \\
\text { (U/mg } \\
\text { protein) }\end{array}$ & $\begin{array}{c}\text { GSH } \\
\text { ( } \mu \mathrm{mol} / \mathrm{g} \\
\text { tissue) }\end{array}$ & $\begin{array}{c}\text { MDA } \\
\text { (nmol/g } \\
\text { tissue) }\end{array}$ \\
\hline C-GP & $23.46 \pm 1.56$ & $58.79 \pm 3.66$ & $38.22 \pm 1.97$ & $7.73 \pm 0.18$ & $4.85 \pm 0.35$ & $38.56 \pm 3.51$ \\
\hline Sitg-GP & $27.92 \pm 1.73$ & $69.58 \pm 3.51$ & $40.62 \pm 1.61$ & $8.64 \pm 0.41$ & $5.92 \pm 0.33$ & $31.14 \pm 1.71$ \\
\hline APAP-GP & $13.83 \pm 1.86$ & $40.95 \pm 3.03$ & $22.57 \pm 1.04$ & $3.34 \pm 0.42$ & $2.41 \pm 0.18$ & $64.47 \pm 2.50$ \\
\hline Sitg+APAP-GP & $21.11 \pm 0.88$ & $56.46 \pm 1.56$ & $33.65 \pm 2.09$ & $7.32 \pm 0.26$ & $4.36 \pm 0.35$ & $41.64 \pm 2.88$ \\
\hline \multicolumn{7}{|l|}{ Multiple comparison } \\
\hline C versusSitg & 0.197 & 0.077 & $0.759^{\mathrm{S}}$ & 0.233 & 0.09 & 0.236 \\
\hline $\mathrm{C}$ versus APAP & $0.001^{*}$ & $0.001^{*}$ & $0.000^{*}$ & $0.000^{*}$ & $0.000^{*}$ & $0.000^{*}$ \\
\hline $\mathrm{C}$ versusSitg $+\mathrm{APAP}$ & 0.71 & 0.949 & 0.257 & 0.824 & 0.684 & 0.854 \\
\hline Sitgversus APAP & $0.000^{*}$ & $0.000^{*}$ & $0.000^{*}$ & $0.000^{*}$ & $0.000^{*}$ & $0.000^{*}$ \\
\hline SitgversusSitg+APAP & $0.019^{*}$ & $0.022^{*}$ & $0.034^{*}$ & $0.006^{*}$ & $0.000^{*}$ & $0.047^{*}$ \\
\hline APAP versusSitg+APAP & $0.011^{*}$ & $0.005^{*}$ & $0.000^{*}$ & $0.000^{*}$ & $0.021^{*}$ & $0.000^{*}$ \\
\hline
\end{tabular}

$\mathrm{C}=$ Control; Sitg=Sitagliptin; APAP $=$ Acetaminophen; $\mathrm{SOD}=$ Superoxide dismutase; $\mathrm{CAT}=$ Catalase; $\mathrm{GPx}=\mathrm{Glutathione}$ peroxidase; GST=Glutathione-S-transferase; GSH=Reduced glutathione; MDA=Malondialdehyde of lipid peroxidation. Each value represented a mean of 10-animals \pm SEM (standard error of the mean). $P=$ Probability; *=Significant difference.

As shown in table (6), the mean tissue levels of TOS and OSI were significantly higher, whilst the mean level of TAC was significantly lower in APAP-GP when compared with their corresponding values of Sitg-GP and C-GP.On the other side, the mean values of TOS and OSI were noted to be significantly decreased, while the mean value of TAC was significantly increased in Sitg+APAP-GP compared to the APAP-GP. In contrast, the mean concentration of TAC was significantly higher in Sitg-GP than Sitg+APAP-GP. 
Table (6): One-way analysis of variance (ANOVA) statistical differences among the experimental groups respecting the levels of TOS and TAC besides calculated OSI in hepatic tissue.

\begin{tabular}{|c|c|c|c|}
\hline \multirow[b]{2}{*}{ Groups } & \multicolumn{3}{|c|}{ Parameters } \\
\hline & $\begin{array}{c}\text { TOS }(\mathrm{mmol} \\
\mathrm{H}_{2} \mathrm{O}_{2} \\
\text { equivalent/g } \\
\text { protein) }\end{array}$ & $\begin{array}{c}\text { TAC }(\mathrm{mmol} \\
\text { Trolox } \\
\text { equivalent/g } \\
\text { protein) }\end{array}$ & $\begin{array}{c}\text { OSI } \\
\text { (Arbitrary } \\
\text { unit) }\end{array}$ \\
\hline C-GP & $14.21 \pm 0.68$ & $1.31 \pm 0.075$ & $11.18 \pm 0.84$ \\
\hline Sitg-GP & $12.37 \pm 0.52$ & $1.55 \pm 0.078$ & $8.26 \pm 0.64$ \\
\hline APAP-GP & $80.3 \pm 5.05$ & $0.79 \pm 0.076$ & $105.47 \pm 4.88$ \\
\hline Sitg+APAP-GP & $16.15 \pm 0.99$ & $1.26 \pm 0.075$ & $13.27 \pm 1.19$ \\
\hline \multicolumn{4}{|l|}{ Multiple comparison } \\
\hline C versus Sitg & 0.959 & 0.148 & 0.851 \\
\hline $\mathrm{C}$ versus APAP & $0.000^{*}$ & $0.000^{*}$ & $0.000^{*}$ \\
\hline $\mathrm{C}$ versusSitg $+\mathrm{APAP}$ & 0.952 & 0.951 & 0.939 \\
\hline Sitg versus APAP & $0.000^{*}$ & $0.000^{*}$ & $0.000^{*}$ \\
\hline Sitg versus Sitg + APAP & 0.737 & $0.048^{*}$ & 0.518 \\
\hline APAP versus Sitg + APAP & $0.000^{*}$ & $0.001^{*}$ & $0.000^{*}$ \\
\hline
\end{tabular}

Tables (7 and 8) present the effects of Sitg pretreatment on APAP-induced histopathological alterations as evaluated by semi-quantitative scoring of severity of lesions, type of hepatic damage, extent of collagen fibrils, and glycogen content.

As exhibit in table (7), the prevalence of hepatic lesions was markedly increased in APAP-GP with moderate to extensive intensity of hepatocellular injury as compared to other groups. However, in Sitg+APAP-GP, the severity of hepatic lesions were substantially lower than those recorded in APAP-GP and exhibited mild to moderate intensity of hepatocellular injury. In contrast, the prevalence and severity of hepatic lesions in Sitg+APAP-GP were still slightly higher than those of C-GP and Sitg-GP.

Table (7): The number and percentage of normal and affected animals among the experimental groups according to semi-quantitative evaluation of the severity of hepatic lesions.

\begin{tabular}{|l|c|c|c|c|c|c|}
\hline \multirow{2}{*}{ Severity of lesions } & \multicolumn{5}{|c|}{ Groups } \\
\cline { 2 - 5 } & $\begin{array}{c}\text { C-GP } \\
\mathbf{n}(\%)\end{array}$ & $\begin{array}{c}\text { Sitg-GP } \\
\mathbf{n ~ ( \% )}\end{array}$ & $\begin{array}{c}\text { APAP-GP } \\
\mathbf{n}(\%)\end{array}$ & $\begin{array}{c}\text { Sitg+APAP-GP } \\
\mathbf{n}(\%)\end{array}$ & $\begin{array}{c}\mathbf{X}^{2} \\
\text { score }\end{array}$ & $\begin{array}{c}\boldsymbol{P} \text { - } \\
\text { value }\end{array}$ \\
\hline Normal $^{@}$ & $10 / 10(100 \%)$ & $\begin{array}{c}10 / 10 \\
(100 \%)\end{array}$ & $0 / 10(0.0 \%)$ & $0 / 10(0.0 \%)$ & & \\
\hline Mild lesions $^{\#}$ & $0 / 10(0.0 \%)$ & $0 / 10(0.0 \%)$ & $0 / 10(0.0 \%)$ & $7 / 10(70 \%)$ & \multirow{2}{*}{0.0001} \\
\hline Moderate lesions $^{\$}$ & $0 / 10(0.0 \%)$ & $0 / 10(0.0 \%)$ & $6 / 10(50 \%)$ & $3 / 10(30 \%)$ & \\
\hline Severe lesions $^{\&}$ & $0 / 10(0.0 \%)$ & $0 / 10(0.0 \%)$ & $3 / 10(30 \%)$ & $0 / 10(0.00 \%)$ & \\
\hline Extensive lesions $^{\Psi}$ & $0 / 10(0.0 \%)$ & $0 / 10(0.0 \%)$ & $1 / 10(10 \%)$ & $0 / 10(0.00 \%)$ & & \\
\hline
\end{tabular}

$\mathrm{C}=$ Control; Sitg=Sitagliptin; APAP $=$ Acetaminophen; $@=<10 \%$ of fields affected; $\#=>10 \%-<25 \%$ of fields affected; $\$=>25 \%-<50 \%$ of fields affected; $\&=>50 \%-<75 \%$ of fields affected; $\Psi=>75 \%$ of fields affected; $P=$ Probability; $*=$ Significant difference. 
As demonstrate in table (8), the mean semi-quantitative scores for type of hepatic damage and collagen fibrils extension were significantly higher, whilst glycogen content were significantly lower in APAP-GP when compared with their corresponding grades in the Sitg-GP and C-GP. Nonetheless, in Sitg-APAP-GP, the mean scores for type of hepatic damage and collagen fibrils extension were significantly reduced, while the mean grade of glycogen content was significantly raised when matched with their corresponding grades in the APAP-GP. In contrast, the mean grade for type of hepatic damage in Sitg+APAP-GP delineated slight significant increment when compared with Sitg-GP and C-GP.

Table (8): One-way analysis of variance (ANOVA) statistical differences among the experimental groups relating to semi-quantitative scores of hepatic damage, collagen fibrils extension, and glycogen content.

\begin{tabular}{|l|c|c|c|}
\hline \multirow{2}{*}{ Groups } & \multicolumn{3}{|c|}{ Parameters } \\
\cline { 2 - 4 } & $\begin{array}{c}\text { Hepatic damage } \\
\text { (maximum score of 18) }\end{array}$ & $\begin{array}{c}\text { Collagen fibrils } \\
\text { (maximum score of 4) }\end{array}$ & $\begin{array}{c}\text { Glycogen content } \\
\text { (maximum score of } \\
\text { 3) }\end{array}$ \\
\hline C-GP & $0.45 \pm 0.04$ & $0.36 \pm 0.02$ & $2.93 \pm 0.03$ \\
\hline Sitg-GP & $0.43 \pm 0.02$ & $0.35 \pm 0.02$ & $2.95 \pm 0.02$ \\
\hline APAP-GP & $8.86 \pm 0.45$ & $2.42 \pm 0.04$ & $1.48 \pm 0.12$ \\
\hline Sitg+APAP-GP & $1.75 \pm 0.35$ & $0.50 \pm 0.07$ & $2.74 \pm 0.05$ \\
\hline Multiple comparison & \multicolumn{3}{|c|}{} \\
\hline C versus Sitg & 1 & 1 & 0.996 \\
\hline C versus APAP & $0.000^{*}$ & $0.000^{*}$ & $0.000^{*}$ \\
\hline C versus Sitg+APAP & $0.013^{*}$ & 0.091 & 0.24 \\
\hline Sitgversus APAP & $0.000^{*}$ & $0.000^{*}$ & $0.000^{*}$ \\
\hline Sitg versus Sitg+APAP & $0.011^{*}$ & 0.078 & 0.161 \\
\hline APAP versus Sitg+APAP & $0.000^{*}$ & $0.000^{*}$ & $0.000^{*}$ \\
\hline
\end{tabular}

$\mathrm{C}=$ Control; Sitg=Sitagliptin; $\mathrm{APAP}=$ Acetaminophen; vs=versus. Each value represented a mean of 10 animals $\pm \mathrm{SEM}$ (standard error of the mean). $P=$ Probability; ${ }^{*}=$ Significant difference.

Figures (1-6) illustrate the effects of Sitg pretreatment on APAP-induced changes in hepatic architectures as indicated by Hematoxylin and Eosin stain (Hx\&E).

Light microscopic examination of $\mathrm{Hx} \& \mathrm{E}$ stained liver sections obtained from C-GP (Figure 1) and Sitg-GP (Figure 2) showed normal hepatic lobules consist of branching and anastomosing hepatocytes cords radiating from the central vein and separated by blood sinusoids. The sinusoids appeared as narrow spaces lined by flattened endothelial cells and von kupffer cells. Liver cells appeared polyhedral in shape with acidophilic (red or pink) cytoplasm and large round central blue nuclei. Portal tracts contain the portal triad (branch of portal vein, branch of hepatic artery, and bile ducts).

However, examination of $\mathrm{Hx} \& \mathrm{E}$ stained liver sections prepared from APAP-GP (Figures 3-5) revealed numerous histopathological changes in their hepatic architectures such as focal lobular necrosis of hepatocytes, hepatic parenchymal hemorrhage, 
intracellular vacuolar degeneration and cloudy swelling of hepatocytes, central vein congestion and dilatation, portal and lobular inflammatory cell infiltrations, and sinusoidal dilatation.
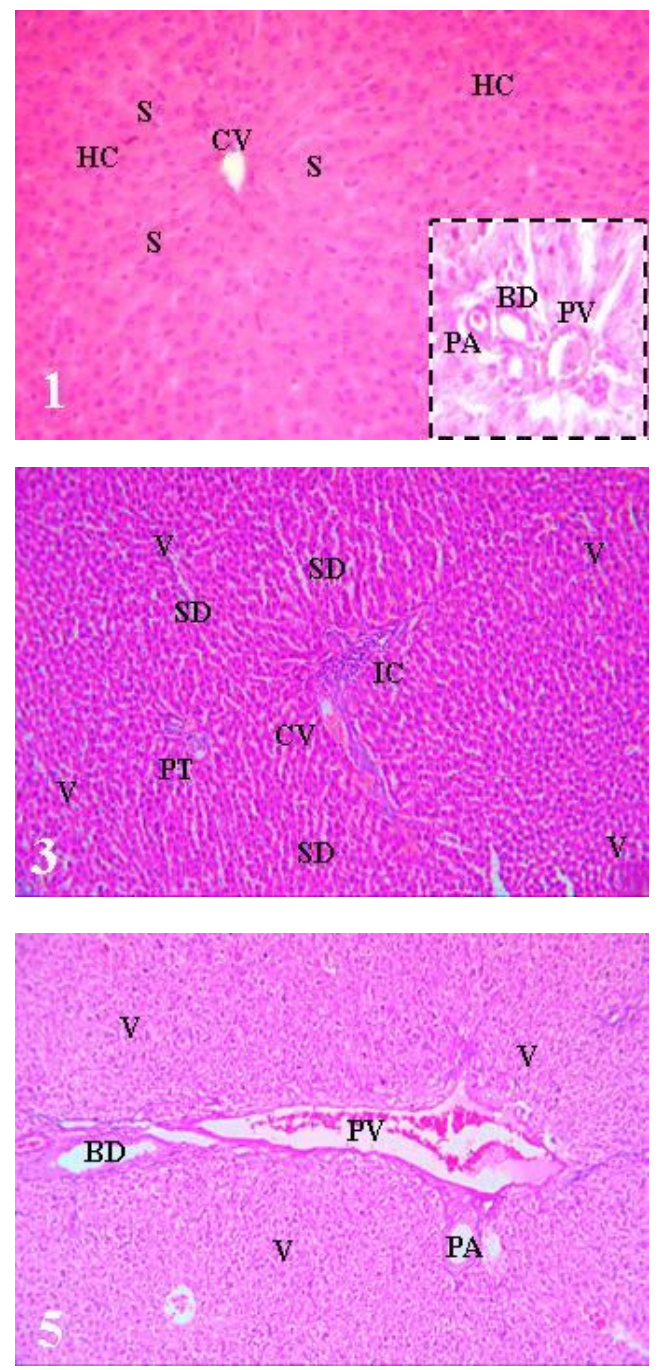

Whereas, investigation of Hx\&E stained liver sections processed from Sitg+APAP-GP (Figure 6) exhibited less severe hepatic tissue injury and lower incidence of the previously mentioned histomorphological lesions when compared to APAP-GP.
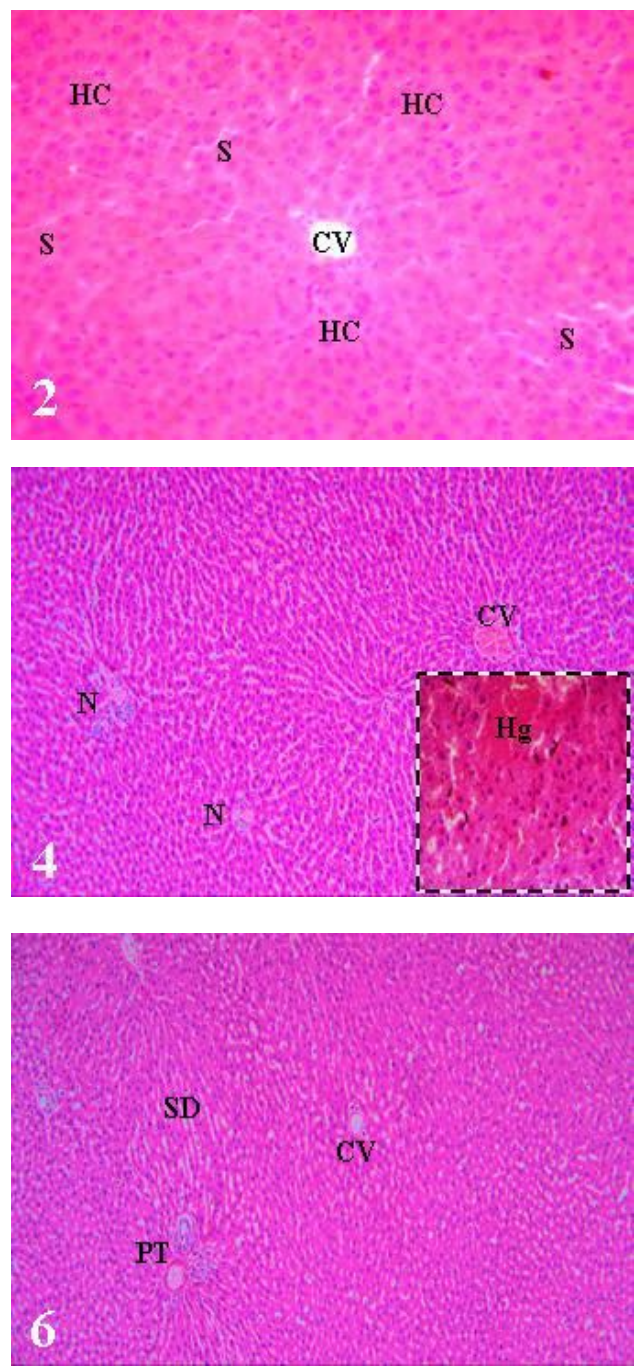

Figs. (1-6): Photomicrographs of Hx\&E-stained liver sections (Original Magnification; OM x 100). Figs. (1 and 2):Cgroup and Sitg-treated group, respectively, showing normal hepatic lobules consists of cords of hepatocytes (HC) with rounded central basophilic nucleoli radiating from central vein (CV) and separated from each other by normal blood sinusoids (S). Small window illustrates normal portal tract triad of portal vein (PV), portal artery (PA), and bile ducts (BD). Figs. (3-5): APAP-treated group showing marked degenerative changes like central vein congestion and dilatation (CV), inflammatory cell infiltrations (IC), vacuolated hepatocytes $(\mathrm{V})$, sinusoidal dilatation (SD), portal triad damage (PT), hepatocytes necrotic areas $(\mathrm{N})$, parenchymal hemorrhage $(\mathrm{Hg}$; small window), and portal vein congestion and dilatation (PV). Fig. (6): Sitg+APAP-treated group showing mild hepatic lesions. 
Figures (7-10) illustrate the effects of Sitg pretreatment on APAP-induced alterations in collagen fibrils deposition as determined by Masson's trichromestain (MT). Light microscopic examination of MT stained liver sections obtained from C-GP (Figure 7) and Sitg-GP (Figure 8) showed normal distribution of collagen fibers around the portal areas and central veins. However, examination of MT stained liver sections prepared from APAP-GP (Figure 9) revealed massive deposition of collagen fibers in liver parenchymal tissue. Whereas, investigation of MT stained liver sections processed from Sitg+APAP-GP (Figure 10) exhibited normal collagen fibers distribution within hepatic tissue parenchyma when compared to APAP-GP.

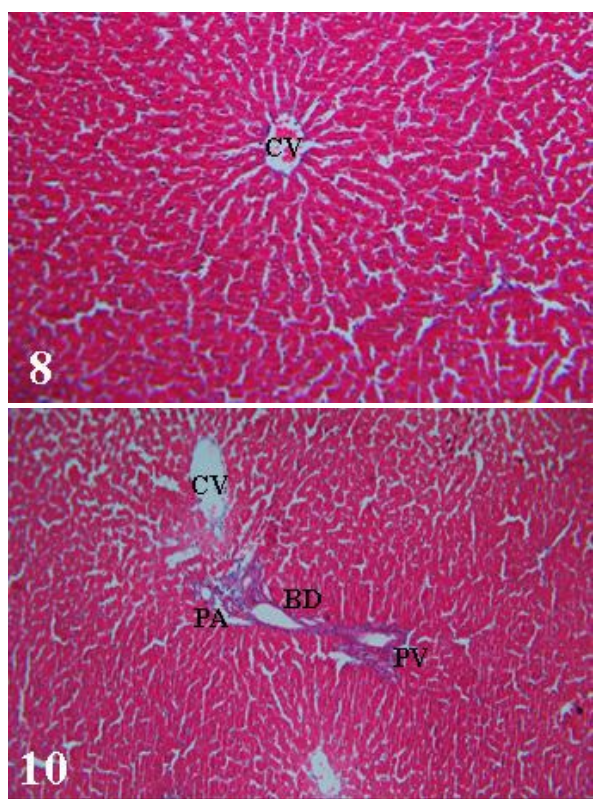

Figs. (7-10): Photomicrographs of Masson's Trichrome-stained liver sections (OM x 100).Figs. (7 and 8):C-group and Sitg-treated group, respectively, showing scanty perivascular deposition of connective tissue around the central vein as well as portal vein (PV), portal artery (PA), and bile ducts (BD) of portal tract triad (small window). Fig. (9): APAP-treated group showing massive deposition of collagen tissue and inflammatory cells (IC) around dilated central vein as well as dilated portal vein (PV), portal artery (PA), and bile ductule (BD) of portal tract triad. Fig. (10): Sitg+APAP-treated group showing normal distribution of the scanty collagen fibrous tissue around dilated central vein and portal tract triad.

Figures (11-14) illustrate the effects of Sitg pretreatment on APAP-induced changes in glycogen contents of hepatocytes as examined by periodic acid-Schiff stain (PAS).

Light microscopic examination of periodic acid-Schiff (PAS) stained liver sections obtained from C-GP (Figure 11) and Sitg-GP (Figure 12) showed a strong PASpositive reaction for glycogen granules in the cytoplasm of hepatocytes around the central vein and other areas of the liver lobule.

However, examination of PAS stained liver sections prepared from APAP-GP (Figure 13) revealed a weak PAS-positive reaction for glycogen content in the cytoplasm of hepatocytes principally in the centrilobular areas and/or midzonal region of the hepatic acinus, which indicating reduction of glycogen content of hepatocytes. 
Whereas, investigation of PAS stained liver sections processed from Sitg+APAP-GP (Figure 14) exhibited a moderate to strong PAS-positive reaction for glycogen content in the cytoplasm of hepatocytes in central and portal regions of the liver acinus, which were nearly similar to those in the C-GP, indicating higher glycogen content of hepatocytes than those of APAP-GP.
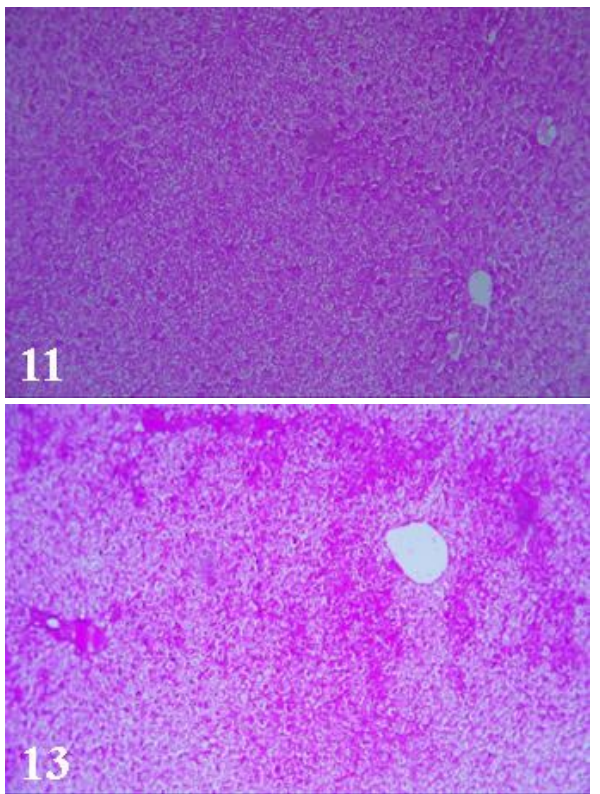
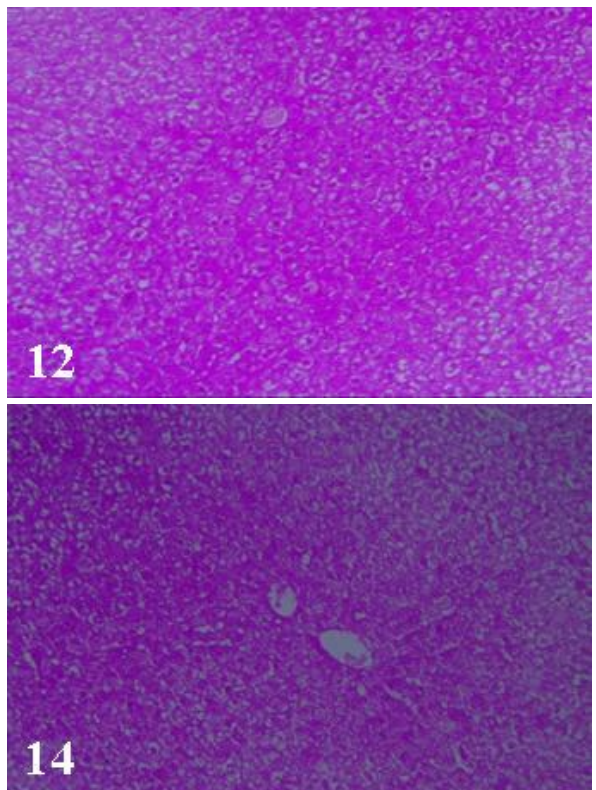

Figs. (11-14): Photomicrographs of PAS-stained liver sections (OM x 100). Figs. (11 and 12): C-group and Sitg-treated group, respectively, showing strong PAS positive staining of glycogen contents in the hepatocytes. Fig. (13): APAP-treated group showing vacuolated hepatocytes with reduced glycogen accumulation in most of the hepatocytes (light stained areas) as well as positive PAS reaction for glycogen materials in some hepatoctyes (dark stained areas). Fig. (14): Sitg+APAP-treated group showing strong PAS positive staining of the hepatocyte glycogen storage.

\section{Discussion}

Acetaminophen (APAP) is among the most commonly worldwide used analgesicantipyretic drugs (Adil et al., 2016). Poisoning by APAP is an important cause of hepatotoxicity and accounts for approximately one-half of all cases of acute liver failure in the United States and Great Britain (Hinson et al., 2010). Thus, different treatment strategies have been suggested to ameliorate or prevent APAP-induced hepatotoxicity (Bessems and Vermeulen, 2001).
The current results of APAP-induced changes in liver weights are in harmony with the results of other researchers who have documented a significant increase in the average liver weight to body weight ratio of APAPtreated rats (Adil et al., 2016). Excessive hepatocellular proliferation, hypertrophy, and different pathological changes may contribute to APAP-induced hepatomegaly.

The current findings of APAP-treated rats depicted remarkable liver injury as demonstrated by significant changes in all estimated liver biomarkers. These alterations in liver biomarkers are reinforced by the outcomes of numerous 
other authors who stated that APAP-induced hepatocellular damage in experimental rodents is marked by increased serum or plasma activities of AST, ALT, ALP, GGT, and LDH (Iroanya et al., 2014) besides elevated blood levels of TB, DB, and IB, whereas the blood values of TP, ALB, and GLB were considerably reduced (Imo et al., 2015).

These cytosolic enzymes are indicators of hepatic necrosis and elevations in AST, ALT, and LDH levels in the circulation suggests a leakage in plasma membrane secondary to loss of hepatocellular function and integrity. Also, any alterations in biliary system and/or hepatocytes functions can enhance ALP and GGT synthesis and discharge into blood (Iroanya et al., 2014; Adil et al., 2016). Impairment of liver parenchymal cell function and/or bile canaliculi obstruction by cellular swelling or inflammation can result in defective bile transport and flow with subsequent development of hyperbilirubinemia (Adil et al., 2016).

The decreases in serum proteins may be attributed to a decline in the number of hepatocytes responsible for protein synthesis or endoplasmic reticulum damage with loss of CYP P450 function as a result of APAPinducedcellular destruction (Iroanya et al., 2014; Sayed and El-Kordy, 2014).

Data of the present study exhibited that administration of APAP resulted in oxidative stress phenomenon due to extensive disturbances in oxidant/antioxidant equilibrium and total redox status. These findings are in accordance with preceding report, which has suggested that oxidative cellular injury and profound LPO are hallmarks of APAP hepatotoxicity as signified by marked depression of hepatic enzymatic (SOD, CAT, GPx, and GST) and non-enzymatic (GSH) antioxidants activities alongside with pronounced elevation of oxidative MDA levels (Iroanya et al., 2014).

The present changes in hepatic total redox status are strengthened by the results of other experimental study which has shown that treatment with APAP causes significant decrease in hepatic TAC levels accompanied with considerable increases in tissue TOS concentrations and OSI expressions (Verma et al., 2016).

The pathogenesis of APAP-induced oxidant stress involves overproduction of free radical derivatives from damaged mitochondria that overwhelm and impair cellular antioxidant capacities to cope with exogenous oxidants injury (Bessems and Vermeulen, 2001).

The present findings of APAP-mediated drastic changes in histomorphological structure of the liver are in line with the results of many other investigators who have semi-quantitatively demonstrated marked histological lesions of hepatic tissue such as portal inflammation, necrosis, vacuolar degeneration, sinusoidal dilatation, and vascular congestion after administration of APAP to adult albino rats (Verma et al., 2016; Elbe et al., 2018).

The mechanisms of APAP-induced hepatic damage occur via a complex array of events. Excessive metabolism of APAP leads to overproduction of the toxic metabolite NAPQI, which in turn depletes glutathione contents and covalently reacts with cellular macromolecules components such as proteins, lipids, and DNA, causing formation of protein adducts and LPO. Adduct formation interrupts protein structure and/or function, resulting in destruction of membrane organelles, metabolic pathways, and/or cytological vital processes. Increased hepatocellular formation of reactive oxygen species (ROS) and reactive nitrogen species will 
lead to oxidative damage of hepatocytes. Increased oxidative stress is coupled with disruptions in calcium homeostasis and stimulation of signal transduction responses that can induce mitochondrial toxicity with consequent depletion of ATP synthesis (Bessems and Vermeulen, 2001; Hinson et al., 2010).

Associated with these essential events there is a second phase of injury mediated by complex inflammatory response processes, which triggered by release of certain products from necrotic cells. In response to these changes various non-parenchymal cells, especially Kupffer cells (resident hepatic macrophages), secrete a number of certain cytokines and chemokines, that activate and recruit a variety of inflammatory cells into the liver, which have the capacity to cause additional tissue injury through further generation of ROS (Bessems and Vermeulen, 2001).

The existing work showed that APAPmediated marked enhancement of collagen fibrous deposition. Similarly, other researchers have reported an increase in collagen tissue accumulation in liver induced by APAPin experimental animals (Sayed and El-Kordy, 2014; Henrique da Silva et al., 2015; Bai et al., 2017). Several authors imply that APAP and NAPQI can stimulate activation and trans-differentiation of hepatic stellate cells to myofibroblast-like cells with consequent extensive deposition of $\alpha$-smooth muscle actin ( $\alpha$-SMA) and types I and IIIcollagens in the liver (Bai et al., 2017).

The current work revealed that APAPmediated extensive depletion of hepatocyte glycogen contents. Analogously, several experimental studies concerned with APAP toxicity have documented depletion of hepatocyte glycogen contents (Henrique da
Silva et al., 2015; Elbe et al., 2018). The experimental in vitro results of Itinose et al. (1989) have shown that APAP has profound negative influences on metabolism of isolated perfused rat liver. The drug or its reactive metabolite can inhibit the processes of mitochondrial energy metabolism, gluconeogenesis, carbohydrate metabolism, glycogen synthesis, and nutrients absorption by the hepatocytes.

The contemporary results of all investigated parameters were comparable between Sitg-treated and untreated control animals, indicating that Sitg at the tested dose is well tolerated and has no hepatotoxic effects. Similarly, several results indicate that Sitg is effective and safe drug when administered to experimental animals and it has not been associated with any significant changes in liver function or morphology (Alam et al., 2015; Onoyama et al., 2015; Abo-Haded et al., 2017).

This study showed that pretreatment with Sitg significantly prevented the changes in liver weights of APAP-treated animals, which is in line with else experimental study illustrating that Sitg has significantly reduced hepatomegalyinduced by dexamethasone (Mathai et al., 2015). It has been speculated that Sitg can reverse these deleterious effects of APAP on liver weights through inhibition of the inflammatory-apoptotic degenerative process (Abo-Haded et al., 2017).

In the current study, prior oral administration of Sitg exhibited significant hepatoprotective activities against APAP toxicity as manifested by pronounced prevention of APAP-induced abnormalities in liver biomarkers, oxidant-antioxidant indices, and total redox potential profiles. Similarly, Sitg has shown hepatoprotective activity against anticancer drug methotrexate- and carbon tetrachloride-induced hepatotoxicity (AboHaded et al., 2017; Sokar et al., 2017) as well as 
experimentally induced non-alcoholic steatohepatitis (Jung et al., 2014; Onoyama et al., 2015), hepatic steatosis (Mathai et al., 2015), and diabetic liver injury (Hassan et al., 2012; Huang et al., 2017). Additionally, other experimental studies have elucidated drastic improvement of abnormal liver markers towards respective normal values after administration of Sitg to animal models (AboHaded et al., 2017; Huang et al., 2017; Sokar et al., 2017).

The current work revealed that pretreatment with Sitg greatly counteracted APAP-induced oxidative stress in liver tissue. Correspondingly, many previous studies have displayed that Sitg has beneficial effects in prevention of oxidative stress associated with different conditions of disease- or toxicinduced liver injury as evidenced by significant increases in blood or tissue levels of some enzymatic and non-enzymatic antioxidant contents together with decreases in the levels of MDA marker of free radicalsinduced LPO (Alam et al., 2015; Abo-Haded et al., 2017; Huang et al., 2017; Sokar et al., 2017).

Moreover, many manuscripts have shown that Sitg causes improvement of cellular total redox potential profiles of hepato-renal tissues in experimentally induced hepatotoxicity and renal ischemia reperfusion injury as manifested by elevations of TAC concentrations and depressions of TOS levels and OSI expressions (Nuransoy et al., 2015; Abo-Haded et al., 2017).

The current study showed that prior oral administration of Sitg exerted significant protective effects against APAP-induced abnormalities in liver structure, collagen fibers deposition, and hepatocyte glycogen contents. These findings are in agreement with prior studies demonstrating that administration of Sitg markedly ameliorated hepatic pathological lesions in experimental models of xenobiotic-mediated hepatotoxicity such as methotrexate and carbon tetrachloride (Abo-Haded et al., 2017; Sokar et al., 2017), non-alcoholic steatohepatitis (Jung et al., 2014; Onoyama et al., 2015), and type 2 diabetes mellitus (Hassan et al., 2012; Huang et al., 2017). Furthermore, several experimental studies have elucidated that treatment with Sitg markedly alleviates deposition of collagen fibrous in the liver (Jung et al., 2014; Onoyama et al., 2015; Sokar et al., 2017) and largely prevents reduction in hepatocyte glycogen storage (Hassan et al., 2012).

Multiple and complex pathophysiological mechanisms have been proposed for the hepatoprotective role of Sitg. Evidences from a variety of experimental model studies points out that the DPP-inhibitor Sitg plays an important role in the alleviation of different complications of organs toxicities through modulation of oxidative-inflammatory-apoptotic signaling pathways, which contributing to its protective effects (Nuransoy et al., 2015; Abo-Haded et al., 2017).

Several results suggest that Sitg can protect the liver from different harmful effects by acting as anti-oxidative stress agent with subsequent relieving of oxidative stress and endoplasmic reticulum stress. Pretreatment with Sitg stimulates up-regulation of protein transcription and expression of antioxidant proteins, resulting in induction of antioxidant enzymes formation such as SOD, CAT, and GPx that can protect hepatic tissue against oxidative damage (Jung et al., 2014; Abo-Haded et al., 2017).

Furthermore, Sitg can ameliorate the progression of hepatotoxicity via downregulation of the transcription of many cytotoxic pro-inflammatory genes like cytokine and chemokine. This anti-inflammatory activity of 
Sitg is supported by down-regulation in the hepatocellular mRNA expressions of many inflammatory markers. Also, Sitg can prevent production of the potent cytotoxic oxidant peroxynitrite (Onoyama et al., 2015; AboHaded et al., 2017). Moreover, Sitg can significantly decreases DNA fragmentation and apoptosis (Jung et al., 2014; Onoyama et al., 2015; Abo-Haded et al., 2017).

The anti-fibrotic effect of Sitg is mediated mainly via inhibition of HSCs activation signaling pathways that led to the suppression of collagen synthesis. Also, Sitg can reduce 4-hydroxyproline levels (a major component of the protein collagen formation) and decrease accumulation of fibronectin in the liver (Jung et al., 2014; Onoyama et al., 2015; Sokar et al., 2017).

Taking together, the anti-oxidative stress, anti-inflammatory, anti-apoptotic, and anti-fibrotic actions of Sitg can preserve hepatocellular glycogen contents through protection of the normal architecture and blood flow into the liver therefore, promotes the nutrients to be absorbed by the hepatocytes and enhances glycogen synthesis (Jung et al., 2014; Sokar et al., 2017).

\section{Conclusion}

Results of the present study elucidate several toxicological consequences in experimental rats as a result of exposure to APAP. These findings include gain in absolute and relative weights of liver, prominent changes in the serum levels of all investigated liver biomarker enzymes, oxidative stress phenomenon with considerable disturbance in hepatic oxidants/antioxidants balance and altered total redox status. These abnormalities in serum biochemical and tissue oxidative stress parameters are supported by significant distortions in hepatic histological architecture, enhancement of extracellular collagen fibrils deposition, and reduction in hepatocyte glycogen contents. However, prior oral administration of Sitg exerts hepatoprotective effects against APAP-induced hepatotoxicity as evidenced by marked prevention of all APAP-induced abnormalities in biochemical indices and histopathological structure.

\section{References}

Abo-Haded, H.M.; Elkablawy, M.A.; Aljohani, Z.; et al. (2017): "Hepatoprotective effect of sitagliptin against methotrexate induced liver toxicity". PLoS ONE, 12:e0174295.

Adil, M.; Kandhare, A.D.; Ghosh, P.; et al. (2016): "Ameliorative effect of naringin in acetaminophen-induced hepatic and renal toxicity in laboratory rats: role of FXR and KIM-1". Ren. Fail., 38:10071020 .

Aebi, H. (1984): "Catalase in vitro". Methods Enzymol., 105:121-126.

Alam, M.A.; Chowdhury, M.R.H.; Jain, P.; et al. (2015): "DPP-4 inhibitor sitagliptin prevents inflammation and oxidative stress of heart and kidney in two kidney and one clip (2K1C) rats". Diabetol. Metab. Syndr., 7:107.

Bai, Q.; Yan, H.; Sheng, Y.; et al. (2017): "Long-term acetaminophen treatment induced liver fibrosis in mice and the involvement of Egr-1".Toxicology, $382: 47-58$.

Batcioglu, K.; Gul, M.; Uyumlu, A.B; et al. (2009): "Liver lipid peroxidation and antioxidant capacity in cerulein-induced 
acute pancreatitis". Braz. J. Med. Biol. Res., 42:776-782.

Belfield, A. and Goldberg, D.M. (1971): "Revised assay for serum phenyl phosphatase activity using 4-aminoantipyrine". Enzyme, 12:561-573.

Bessems, J.G. and Vermeulen, N.P. (2001): "Paracetamol (acetaminophen)induced toxicity: molecular and biochemical mechanisms, analogues and protective approaches". Crit. Rev. Toxicol., 31:55-138.

Beutler, E.; Durgun, O. and Kelly, B.M. (1963): "Improved method for the determination of blood glutathione". J. Lab. Clin. Med., 51:882-888.

Buhl, S.N. and Jackson, K.Y. (1978): "Optimal conditions and comparison of lactate dehydrogenase catalysis of the lactate-to-pyruvate and pyruvateto-lactate reactions in human serum at 25, 30, and 37 degrees C". Clin. Chem., 24:828-831.

Çeriğ, S.; Geyikoglu, F.; Bakır, M.; et al. (2016): "Hepatoprotective effect of Oleuropein against cisplatin-Induced liver damage in rat". Int. J. Med. Health Biomed. Bioeng. Pharm. Eng., 10:255-262.

Dart, R.C.; Erdman, A.R.; Olson, K.R.; et al. (2006): "Acetaminophen poisoning: an evidence based consensus guideline for outof-hospital management". Clin. Toxicol. (Phila), $44: 1-18$.

Doumas, B.T.; Watson, W.A. and Biggs, H.G. (1971): "Albumin standards and the measurement of serum albumin with bromocresol green". Clin. Chem. Acta., 31:87-96.
Elbe, H.; Gul, M.; Cetin, A.; et al. (2018): "Resveratrol reduces light and electron microscopic changes in acetaminopheninduced hepatotoxicity in rats: Role of iNOS expression".Ultrastruct. Pathol., 42:39-48.

Erel, O.A. (2004): "Novel automated direct measurement method for total antioxidant capacity using a new generation, more stable ABTS radical cation". Clin. Biochem., 37:277-285.

Erel, O.A. (2005): "New automated colorimetric method for measuring total oxidant status". Clin. Biochem., 38:1103-1111.

Fontana, R.J. (2008): "Acute liver failure including acetaminophen overdose". Med. Clin. North. Am., 92:761-794.

Gamble, M. and Wilson, I. (2002): The Hematoxylins and Eosin. In: Theory and practice of histologial techniques. J. D. Bancroft and M. Gamble (Eds.), $5^{\text {th }}$ d, Elsevier Pub., Elsevier, Philadelphia, PA, USA. P.P. 125-138.

Gornall, A.G.; Bardawill, C.J. and David, M.M. (1949): "Determination of serum protein by means of Biuret reaction". J. Biol. Chem., 177:751-766.

Habig, W.; Pabst, M. and Jakoby, W. (1974):

"Glutathione S-transferases: the first enzymatic step in mercapturic acid formation". J. Biol. Chem., 249:71307139.

Hassan, M.I.; El-Gharabawy, G.S. and Moustafa A.A. (2012): "The effect of Sitagliptin (Januvia) on the liver of adult Albino rats in cases of experimental diabetes mellitus (Microscopic and laboratory studies)". Egypt J. Hosp. Med., 47:260-278. 
He, Y.T.; Liu, D.W.; Ding, L.Y.; et al. (2004): "Therapeutic effects and molecular mechanisms of antifibrosis herbs and selenium on rats with hepatic fibrosis". World J. Gastroenterol., 10:703-706.

Henrique da Silva, G.; Barros, P.P.; Silva Gonçalves, G. M.; et al. (2015): "Hepatoprotective effect of Lycopodiumclavatum $30 \mathrm{CH}$ on experimental model of paracetamolinduced liver damage in rats". Homeopathy, 104:29-35.

Hinson, J.A.; Roberts, D.W. and James, L.P. (2010): "Mechanisms of acetaminophen-induced liver necrosis". Handb. Exp. Pharmacol., 196:369-405.

Huang, X.L.; He, Y.; Ji, L.L.; et al. (2017): "Hepatoprotective potential of isoquercitrin against type 2 diabetesinduced hepatic injury in rats". Oncotarget, 8:101545-101559.

Imo, C.; Uhegbu, F.O.; Glory, I.N.; et al. (2015): "Histological and hepatoprotective effect of ethanolic leaf extract of Gongronema Latifolium Benth in acetaminopheninduced hepatic toxicity in male albino rats". Int. J. Preventive Med. Res., 1:217-226.

Iroanya, O.O.; Adebesin, O.A. and Okpuzor, J. (2014):"Evaluation of the hepato and nephron-protective effect of a polyherbal mixture using wistar albino rats".J. Clin. Diagn. Res., 8:HC15-HC21.

Itinose, A.M.; Sakuno, M.L and Bracht, A. (1989): "Metabolic effects of acetaminophen. Studies in the isolated perfused rat liver". Cell Biochem. Funct., 7:263-273.
Itou, M.; Kawaguchi, T.; Taniguchi; et al. (2013): "Dipeptidyl peptidase-4: a key player in chronic liver disease". World J. Gastroenterol., 19:2298-306.

Jaeschke, H.; Williams, C.D.; McGill, M.R.; et al. (2010): "Herbal extracts ahepatoprotectants against acetaminophen hepatotoxicity". World J. Gastroenterol., 16:2448-2450.

Jones, M.L. (2002): Connective Tissues and Stains. In: Theory and practice of histologial techniques. J. D. Bancroft and M. Gamble (Eds.), $5^{\text {th }}$ ed, Elsevier Pub., Elsevier, Philadelphia, PA, USA. P.P. 139-162.

Jung, Y.A.; Choi, Y.K.; Jung, G.S.; et al. (2014): "Sitagliptin attenuates methionine/ choline-deficient dietinduced steatohepatitis". Diabetes Res. Clin.Pract., 105:47-57.

Kane, A.E.; Mitchell, S.J.; Machetal, J; et al. (2016): "Acetaminophen hepatotoxicity in mice: effect of age, frailty and exposure type". Exp. Geronto., 73:95106.

Lancaster, E.M.; Hiatt, J.R. and Zarrinpar, A. (2014): "Acetaminophen hepatotoxicity: an updated review". Arch. Toxicol., 89:193-199.

Lee, W.M. (2004): "Acetaminophen and the U.S. Acute Liver Failure Study Group: lowering the risks of hepatic failure". Hepatology, 40:6-9.

Mathai, P.; Nayak, N.; Rao, M.; et al. (2015): "Comparison of the efficacy of sitagliptin with pioglitazone on dexamethasone - induced hepatic steatosis, dyslipidemia and hyperglycemia in albino rats". Int. J. Basic Clin. Pharmacol., 4:60-64. 
Nishikimi, M.; Roa, N.A. and Yogi, K. (1972): "Measurement of superoxide dismutase". Biochem.Bioph. Res. Common., 46:849-854.

Nuransoy, A.; Beytur, A.; Polat, A.; et al. (2015): "Protective effect of sitagliptin against renal ischemia reperfusion injury in rats".Ren.Fail., 37:687-693.

Onoyama, T.; Koda, M.; Okamoto, T.; et al. (2015): "Therapeutic effects of the dipeptidyl peptidase-IV inhibitor, sitagliptin, on non-alcoholic steatohepatitis in FLS-ob/ob male mice". Mol. Med. Rep., 12:68956902.

Paglia, D.E. and Valentine, W.N. (1967): "Studies on the quantitative and qualitative characterization of erythrocyte glutathione peroxidase". J. Lab. Clin. Med., 70:158-169.

Reitman, S. and Frankel, S. (1957): "A colorimetric method for the determination of serum glutamic oxalacetic and glutamic pyruvic transaminases". Am. J. Clin. Pathol., 28:56-63.

Satoh, K. (1978): "Serum lipid peroxide in cerebrovascular disorders determined by a new colorimetric method". Clin. Chim. Acta., 90:37-43.

Sayed, M.M. and El-Kordy, E.A. (2014): "The protective effect of curcumin on paracetamol-induced liver damage in adult male rabbits: biochemical and histological studies". Egypt J. Histol., 37:629-639.
Sokar, S.S.; El-Sayad, M.E.; Ghoneim, M.E.; et al. (2017): "Combination of Sitagliptin and Silymarinameliorates liver fibrosis induced by carbon tetrachloride in rats".Biomed. Pharmacother., 89:98-107.

Szasz, G. (1969): "A kinetic photometric method for serum gammaglutamyltranspeptidase". Clin. Chem., 15:124-136.

Tokyol, C.; Yilmaz, S.; Kahraman, A.; et al. (2006): "The Effects of Desferrioxamine and Quercetin on liver injury induced by hepatic ischaemia-reperfusion in rats". Acta.Chir. Belg., 106:68-72.

Totty, B. (2002): Mucins. In: Theory and practice of histologial techniques. J. D. Bancroft and M. Gamble (Eds.), $5^{\text {th }}$ d, Elsevier Pub., Elsevier, Philadelphia, PA, USA. P.P. 163-200.

Verma, P.K.; Raina, R.; Sultana, M.; et al. (2016): "Acetaminophen induced oxidative and histopathological alterations in hepatic tissue: protective effects of Alstonia Scholarisleaf extracts". Pharmacogn. J., 8:385-391.

Walters, M.I. and Gerarde, H. (1970): "An ultramicromethod for the determination of conjugated and total bilirubin in serum or plasma". Microchem. J., 15: 231-243.

Yano, C.L. and Dolder, H. (2002): "Rat testicular structure and ultrastructure after paracetamol treatment". Contraception, 66:463-467. 


\title{
القدرة الوقائية المحتملة لعقار السيتاجلبتيز (جانوفيا) ضد السمية الكبدية المحدثة بواسطة

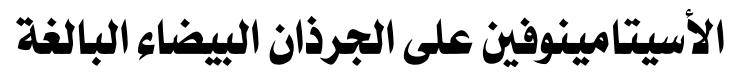

\author{
محمد فريد خضيرى'، شريفة عبد السلام مرسي' \\ من أقسام 'الطب الثرعى والسموم الإكلينيكية، و بالأنسجة وبيولوجيا الخلايا

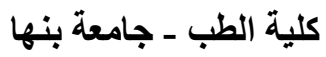

أسيتامينوفين عقار مسكن وخـافض للحر ارة شـائع الاستخدام. الجرعة الزائدة من الأسيتامينوفين مشكلة سريرية عالميـة كبيرة في الانسان. أظهر عقار السيتاجلبتين المضاد للسكر قدرة وقائيـة ضد تسمم الأعضاء.

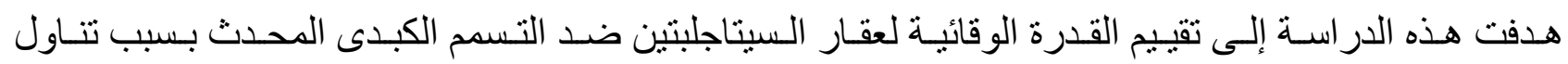
الأسيتامينوفين. أجريت هذه الدر اسة على أربعين من ذكور الجرذان التى قسمت إلى أربع مجمو عات متساوية. المجموعة الأولى (المجموعة الضابطة، تم اعطائها الماء المقطر) ، المجمو عة الثانية (مجمو عـة السيتاجلبتين تم

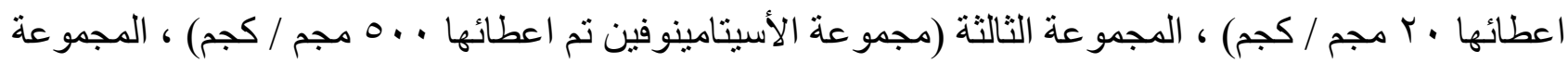

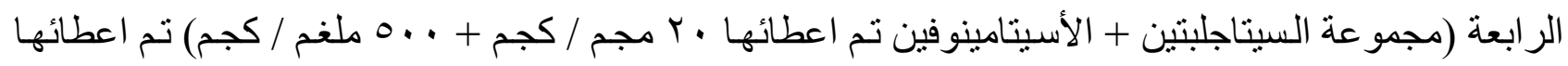
مسبقا السيتاجلبتين ثم إعطائها الأسيتامينوفين بعد مرور ساعتين. أعطيت الجر عات مرة واحدة يوميا عن طريق

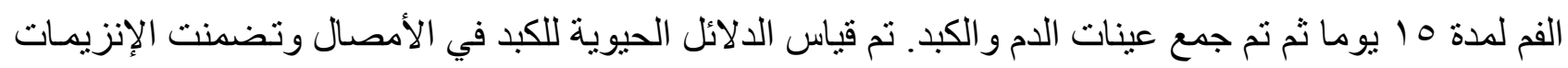

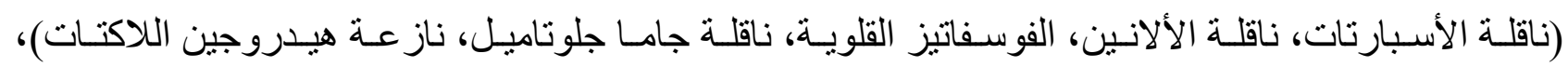

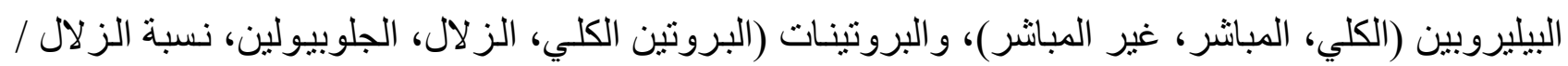
الجلوبيولين). تم قياس الدلائل الحيوية للتأكسد في متجانسات الأنسجة الكبدية وتضمنت مضادات الأنين الأكسدة (فائق أكسيد ديسميوتاز، الكاتـالاز، بيروكسيداز الجلوتـاثيون، ناقلـة الجلوتـاثيون-اس، الجلوتـاثيون المختزل) وثنـائي

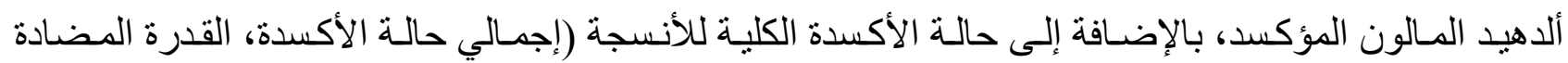

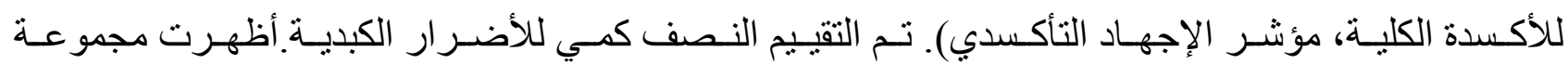

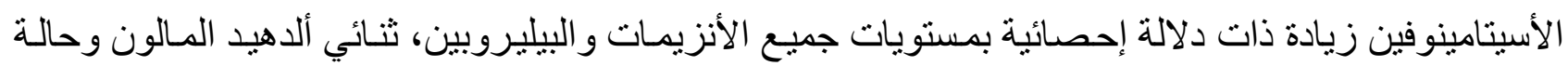

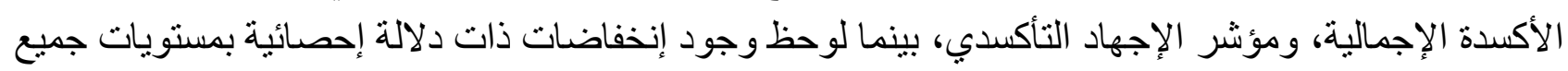

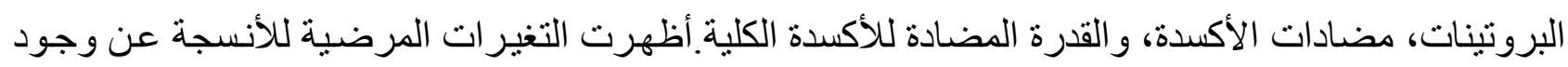
خلل بالبنية الهيكلية، وزيادة فى الترسيبات الليفية، و انخفاض بكميـة الجليكوجين. المعالجة المسبقة بالسيتاجلبتين

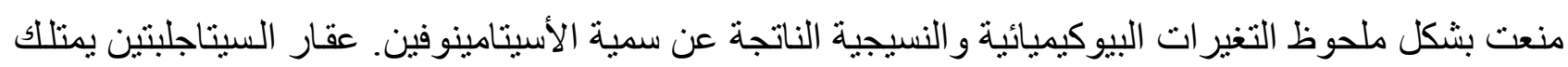
قدرة وقائية_كبدية ملحوظة ضد السمية الكبدية الناتجة عن سمية الأسيتامينوفين والتى يمكن أن تكون مفيدة في

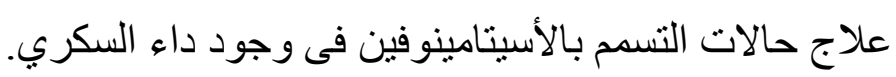

